\title{
Pharmaceutical services in a Mexican pain relief and palliative care institute
}

Raymundo ESCUTIA GUTIÉRREZ, César R. CORTÉZ ÁLVAREZ, Rosa M. ÁLVAREZ ÁLVAREZ, Jorge LV. FLORES HERNÁNDEZ, Jéssica GUTIÉRREZ GODÍNEZ, José G. LÓPEZ Y LÓPEZ.

\begin{abstract}
${ }^{*}$
Neither the purchase nor the distribution of pharmaceuticals in hospitals and community pharmacies in Mexico is under the care of pharmacists. Some are under control of physicians. This report presents the results of the implementation of somef pharmaceutical services for the Jalisco Pain Relief, and Palliative Care Institute (Palia Institute), under the direction of the Secretary of Health, Government of Jalisco. The services implemented were drug distribution system, Drug Information Service, Pharmacovigilance Program , and home pharmacotherapy follow-up pilot program for patients with advanced illness, with the ultimate using the appropriate medication. The drug distribution system included dispensing of opioid pain medications, antidepressants, anticonvulsants, NSAIDs, anxiolytic drugs, steroid drugs, laxatives, and anti-emetics. The frequently used drugs were morphine sulfate (62\%), amitriptyline (6.4\%), and dextropropoxyphene (5.8\%). The Drug Information Service answered 114 consultations, mainly asked by a physician (71\%) concerned with adverse drug reactions and contraindications $(21 \%)$. The pharmacovigilance program identified 146 suspected adverse drug reactions and classified them reasonably as possible $(27 \%)$, probable $(69 \%)$, and certain (4\%). These were attributed mainly to pregabalin and tramadol. The home pharmacotherapy follow-up pilot program cared patients with different cancer diagnoses and drugrelated problems (DRP), which were identified and classified (according to second Granada Consensus) for pharmaceutical intervention as DRP
\end{abstract}

\footnotetext{
Raymundo ESCUTIA GUTIÉRREZ. MSc Parm. Director of the Jalisco Pain Relief, and Palliative Care Institute (Palia Institute), Secretary of Health, Government of Jalisco, (Mexico)

César R. CORTÉZ ÁLVAREZ. MSc Parm. Coordinator of Pharmacy. Faculty of Exact Sciences and Engineering, University de Guadalajara (Mexico).

Rosa Margarita ÁLVAREZ ALVAREZ. PhD. Director of the Jalisco Pain Relief, and Palliative Care Institute, Secretary of Health, Government of Jalisco, (Mexico).

Jorge LV. FLORES HERNÁNDEZ. PhD. Physiology Institute, Autonomous University of Puebla (Mexico). Jéssica GUTIÉRREZ GODÍNEZ. BScPharm. Professor and Coordinator of the Pharmaceutical Services Office, Autonomous University of Puebla (Mexico)

José G. LÓPEZ Y LÓPEZ. PhD. Professor and Director of the Pharmaceutical Services Office. Faculty of Chemical Sciences, Autonomous University of Puebla (Mexico).
}

1 (5\%), DRP 2 (10\%), DRP 3 (14\%), DRP 4 (19\%), DRP 5 (24\%), or DRP 6 (28\%).

This report provides information concerning the accurate use of medication and, above all, an opportunity for Mexican pharmacists to become an part of health teams seeking to resolve drug-related problems.

Keywords: Drug Toxicity. Adverse Drug Reaction Reporting Systems. Mexico.

\section{RESUMEN}

En México, ni la compra ni la distribución de medicamentos en hospitales y farmacias comunitarias están bajo el cuidado de farmacéuticos. Unos cuantos están a cargo de médicos.

Este artículo presenta los resultados de la implementación de algunos servicios farmacéuticos en el Instituto Jaliscience de Alivio al Dolor y Cuidados Paliativos (Instituto Palia), bajo la dirección de la Secretaría de Salud del Gobierno de Jalisco. Los servicios implementados fueron un sistema de distribución de medicamentos, un Servicio de Información de Medicamentos, un programa de Farmacovigilancia, y un programa piloto de seguimiento farmacoterapéutico domiciliario para pacientes con enfermedad avanzada, con el objetivo de utilizar la medicación apropiada. El sistema de distribución de medicamentos incluyó la dispensación de analgésicos opiáceos, antidepresivos,

anticonvulsivantes, AINEs, ansiolíticos, esteroides, laxantes y antieméticos. Los más utilizados fueron sulfato de morfina $(62 \%)$, amitriptilina $(6,4 \%)$ y dextropropoxifeno $(5,8 \%)$. El Servicio de Información de Medicamentos respondió a 114 consultas realizadas principalmente por un médico, concernientes a reacciones adversas $(71 \%)$ y contraindicaciones $(21 \%)$. El programa de Farmacovigilancia identificó 146 sospechas de reacciones adversas y las clasificó como posible (27\%), probable (69\%), y seguras (4\%). Se atribuyeron principalmente a pregabalina y tramadol. El programa piloto de seguimiento farmacoterapéutico domiciliario atendió pacientes con diferentes diagnósticos de cáncer y se identificaron problemas relacionados con medicamentos que se clasificaron (según el Segundo Consenso de Granada) como PRM 1(5\%), PRM 2 (10\%), PRM 3 (14\%), PRM 4 (19\%), PRM $5(24 \%)$, o PRM $6(28 \%)$. 
Este artículo proporciona información relacionada al uso adecuado de medicamentos y, sobre todo ofrece una oportunidad para que los farmacéuticos mexicanos lleguen a ser parte del equipo de salud tratando de resolver los problemas relacionados con medicamentos.

Palabras clave: Toxicidad de medicamentos.

Sistemas de comunicación de reacciones adversas. México.

\section{(English)}

\section{INTRODUCTION}

The World Health Organization (WHO) and the PanAmerican Health Organization have established that one of the primary attributes of pharmacists should be the ability to promote the correct choice and appropriate use of drugs in order to improve the overall quality of health services. ${ }^{1}$ Unlike many other countries, in Mexico the distribution of drugs in hospitals and community pharmacies is generally not overseen by a professional pharmacist. This is one of the reasons that pharmaceutical services have been conceded to be more difficult at the developmental stage. ${ }^{2,3}$ The participation of pharmacists in the development of such services could succeed in the reduction of the costs for patients and increase in their effectiveness in improving patient health. Therefore, we believe it is necessary to integrate pharmaceutical services into the Mexican Health System.

Our objective is to present the results of the first year of implementation of some of the pharmaceutical services developed by the Comprehensive Center of Pharmaceutical Services of the Jalisco Pain Relief and Palliative Care Institute (Palia Institute), under the direction of the Secretary of Health, Government of Jalisco.

The mission of the Comprehensive Center of Pharmaceutical Services is to provide ethical and high-quality pharmaceutical services which aim at improving the quality of life of patients through the correct and safe drug-use investigated by a health team trained in pain control. These services are specifically geared toward patients in advanced stages of disease or with difficulties in controlling pain, as well as the quality of life of the patient's families.

Comprehensive Center of Pharmaceutical Services's vision is to be a reference model for the hospitals pharmaceutical services, such as pharmacovigilance, pharmaceutical-care service for ambulatory patients and drug dispensation.

This reference model is being developed through formulating multidisciplinary health teams and supported by educational institutions and the pharmaceutical industry. The model will be refined through continuing research and publications regarding the rational and safe use of drugs in Mexico, and committing to offer high quality services as well as increasing the number of qualified people for pharmaceutical assistance.

\section{METHODS}

The activities of the Comprehensive Center of Pharmaceutical Services include pharmaceutical care, drug information, pharmacovigilance, drug dispensing, health investigation, education, promotion, and increasing the number of people qualified in pharmaceutical assistance.

\section{Drug Distribution System}

The common objective of the drug distribution system is to ensure that patients have an access to the required quality and safe medication by preservation of the dispensed drugs during storage at the Palia Institute.

The drug distribution is carried out through a proper standardized operating procedure, which includes in- and out- movement, inventory, environmental controls, storage, a prescription model, drug formulary, and the activity profile of the pharmacist and assistants.

The patient is provided medication and offered counseling about the accurate use of a drug, possible adverse drug effects, treatment effectiveness, and recommendations concerning storage of the medicines. The pharmacotherapy follow-up program (PHFP) provides home care by dispensing the medication at patient's doorstep. When a physician personally advises medication, the prescription is received and interpreted, and if it is found correct, the medication is provided. Information about the availability of drugs in the pharmacy is given by means of a constantly updated list

\section{Drug Information Service}

The main objective of the Drug Information Service is to promote accurate drug use through technical, medical, objective, current, and pertinent information that has been duly processed and evaluated before release. For this reason, the Palia Institute health professionals are given training to cope with concrete problems relating to drug usage with particular patients and offering advice to the general public about the appropriate use of medication, with the final goal being achievement of correct pharmacotherapy.

The Drug Information Service has its basis in a standardized operating procedure developed through a questionnaire designed to facilitate the information process. It, however, has primary, secondary, and tertiary information sources.

\section{Pharmacovigilance Program}

The primary objective of the pharmacovigilance program is to identify, evaluate, and notify the suspected adverse drug reactions (ADRs), to guarantee the effectiveness, security, and the quality of drugs, distributed by the Palia Institute pharmacy service. 
The program consists of collecting information about the therapeutic effects and ADRs, caused by the pharmacotherapy of patients receiving physicians' care. Through analyzing health records, carrying out interviews of the patients and their family, and supporting the treating physician, the necessary information is obtained and maintained through the format proposed by the National Center of Pharmacovigilance. The evaluation of the ADRs is done by means of the Naranjo algorithm and Official Mexican Norm NOM-220-SSA1-2004.

\section{Pharmacovigilance Center (Installation and Operation).}

The evaluation of suspected ADRs is completed and presented to the physician to provide support in the decision making for the patient's pharmacotherapy. The report on ADRs is also sent to the National Center of Pharmacovigilance farmacovigilancia@salud.gob.mx via e-mail. All the information is stored on paper and in electronic form for later analysis.

\section{Pilot Program of Home Pharmacotherapy Follow-Up}

The program is based on highlighting the role of the significant pharmacist in the multidisciplinary health team working on activities leading to the detection, prevention, and resolution of drug-related problems. The activities are dynamic, systematic, and documented in collaboration with the patient and the primary caregivers together with the health professionals of Palia Institute, with the goal of reaching concrete results that will improve the quality of life of the patient.

The general objectives, beginning, and evaluation of the Drug Information Service, were implemented under the WHO guidelines ${ }^{4,5}$, the pharmacotherapy follow-up program under the Dader ${ }^{6}$ program, and for the pharmacovigilance program and drug distribution system, in addition to the WHO guidelines, the guidelines of the National Pharmacovigilance Program ${ }^{7}$, and General Health Law of Mexico $^{8}$ are also taken into account. Two criteria were established for inclusion in the pharmacotherapy follow-up program; patients who signed a letter of consent and patients of the Palliative Home Care Program. Through this program patients in the advanced phase of illness had been taken care of by paying home visits by multidisciplinary health team of physicians, nurses, pharmacists, psychologists, and social workers since January 2006. The program had two assistants and a responsible pharmacist, who received logistical support from two university professors from the University of Guadalajara and the Benemérita Universidad Autónoma de Puebla.

In addition, the Comprehensive Center of Pharmaceutical Services has entered into an agreement with the University of Guadalajara through which students majoring in pharmacobiological chemistry will do social service, practice teaching, and present investigational and thesis reports. The agreement also validates international pharmacy students. Under the agreement, in February 2007, one student joined us from the University of Kuopio, Finland, for a threemonth period of teaching practice.

\section{RESULTS}

\section{Drug System Distribution}

The dispensing starts when the pharmacist receives the prescription (Table 1). If it is incomplete, or the pharmacist has any doubts, or the prescribed medication is not available, the pharmacist communicates with the physician for making appropriate changes or choices.

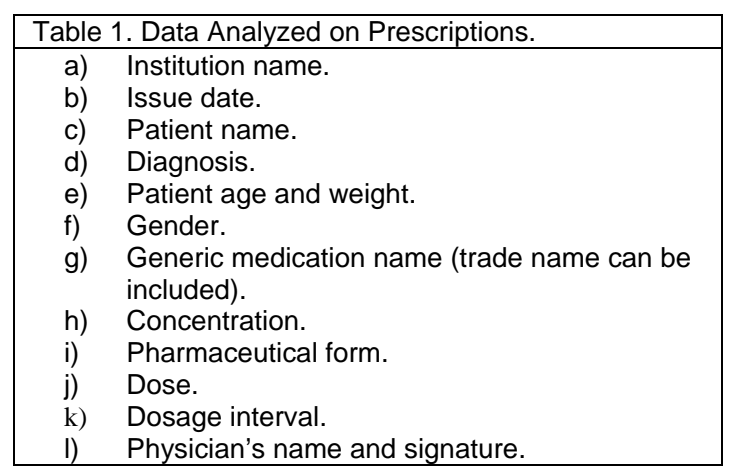

The drugs that the pharmacy prescribes are allopathic in all the pharmaceutical forms such as opioid pain medications, antidepressants, anticonvulsants, non-steroidal anti-inflammatory agents, anxiolytic drugs, steroidal drugs, laxatives, and antiemetics.

The drugs frequently advised by the physicians are morphine sulfate, pregabalin, and amitriptyline (Table 2).

\begin{tabular}{|l|c|}
\hline \multicolumn{1}{|c|}{ Table 2. Medication Use } & \\
\hline \multicolumn{1}{|c|}{ DRUG } & $\%$ \\
\hline Morphine Sulfate & 49.0 \\
\hline Pregabalin & 22.0 \\
\hline Amitriptyline (Hydrochloride) & 5.0 \\
\hline Dextropropoxyphene & 4.5 \\
\hline Methadone (Hydrochloride) & 2.3 \\
\hline Acetaminophen & 1.9 \\
\hline Imipramine & 1.9 \\
\hline Clonazepam & 1.7 \\
\hline Dexamethazone & 1.6 \\
\hline Gabapentin & 1.5 \\
\hline Lidocaine & 1.0 \\
\hline Betamethasone (Disodium Phosphate) & 0.8 \\
\hline Diclofenac Sodium & 0.7 \\
\hline Tramadol & 0.7 \\
\hline Buprenorphine (Hydrochloride) & 0.6 \\
\hline Others & 5.3 \\
\hline
\end{tabular}

\section{Drug Information Service}

To date, 114 consultations have been received, mainly provided by physicians (Table 3 ). The most frequent questions asked have been about ADRs and/or contraindications (Table 4). The average resolution time for the consultations is about 5 minutes.

\section{Pharmacovigilance Program}

To date, 145 potential ADR cases have been identified (from a total of 65 drugs), relating mainly to pregabalin and tramadol (Table 5). Each 
suspected ADR was evaluated and classified by the National Center of Pharmacovigilance (Table 6). We were authorized to notify to the Palia Institute physician's group of the results of the evaluations of the suspected ADR cases found (drowsiness, dry mouth, dizziness, nausea, vomiting, and headache) and of the alternatives or therapeutic adjustments for the well-being of patients.

\begin{tabular}{|c|c|}
\hline CONSULTANT & $\%$ \\
\hline Physician & 71 \\
\hline Patient & 13 \\
\hline Nurse & 7 \\
\hline Pharmacy Staff & 5 \\
\hline Administrative Staff & 3 \\
\hline Social Worker & 1 \\
\hline
\end{tabular}

\begin{tabular}{|l|c|}
\hline \multicolumn{2}{|l|}{$\begin{array}{l}\text { Table 4. Consults provided by the Drug Information } \\
\text { Service according to the nature of the consult. }\end{array}$} \\
\hline \multicolumn{1}{|c|}{ NATURE OF CONSULT } & $\%$ \\
\hline ADRs-Contraindications & 21 \\
\hline Pharmacotherapy of choice & 20 \\
\hline Form sold commercially (pill, capsule, liquid, etc.) & 18 \\
\hline Dosage & 16 \\
\hline Pharmacology & 9 \\
\hline Other & 16 \\
\hline
\end{tabular}

\begin{tabular}{|c|c|}
\hline DRUG & $\%$ \\
\hline Pregabalin & 13 \\
\hline Tramadol & 9.0 \\
\hline Gabapentin & 5.5 \\
\hline Methadone & 4.8 \\
\hline Others & 68 \\
\hline
\end{tabular}

\begin{tabular}{|l|c|}
\hline \multicolumn{2}{|l|}{$\begin{array}{l}\text { Table 6. Evaluation results of suspected cases of } \\
\text { adverse drug reactions. }\end{array}$} \\
\hline \multicolumn{1}{|c|}{ ACCORDING TO CAUSALITY } & $\%$ \\
\hline Possible & 27 \\
\hline Probable & 69 \\
\hline Certain & 4 \\
\hline Doubtful & 0 \\
\hline Unclassifiable & 0 \\
\hline ACCORDING TO SERIOUSNESS & $\%$ \\
\hline Mild & 26 \\
\hline Moderate & 64 \\
\hline Serious & 9 \\
\hline Lethal & 1 \\
\hline
\end{tabular}

\section{Pilot Program of Home Pharmacotherapy Follow-Up}

The group of patients (9) that availed the service complained for somatic pain (55\%), somatic-visceral pain $(11 \%)$, and nonspecific pain (33\%). There were also diagnoses of cancer of the stomach (34\%), colon $(22 \%)$, prostate $(11 \%)$, and other sites $(22 \%)$. By means of successive visits, drug-related problems were detected and classified for the pharmaceutical intervention (Table 7). ${ }^{9}$

\begin{tabular}{|c|c|}
\hline \multicolumn{2}{|c|}{$\begin{array}{l}\text { Table 7. Drug-related problems (DRP) } \\
\text { detected in the home pharmacotherapy } \\
\text { follow-up pilot program. }\end{array}$} \\
\hline TYPE OF DRP & $\%$ \\
\hline DRP type 1 & 5 \\
\hline DRP type 2 & 10 \\
\hline DRP type 3 & 14 \\
\hline DRP type 4 & 19 \\
\hline DRP type 5 & 24 \\
\hline DRP type 6 & 28 \\
\hline
\end{tabular}

\section{DISCUSSION}

Adequate inventory control and systematic documentation of the drugs used in the DDS is considered as the strength of the Center. The narcotics are the most dispensed drug (also called controlled drugs) by the pharmacist. In addition, familiarity with the drugs used most frequently offers advantages for scheduling yearly acquisitions and prioritizing the monographic work on these active principles for adequate dispensing.

Dispensing of drugs at patients' homes offers the opportunity to implement a home pharmacotherapy follow-up pilot program.

The Drug Information Service has fulfilled the minimum requirements to reach the second stage (a formal drug information service) and our results provide evidence for the trust placed in the health team to identify and resolve problem relating to the use of medication, mainly concerning ADRs and contraindications. A weakness of the Drug Information Service is the lack of indicators of quality and the impact of the information, because we only had data of the number and nature of consults, along with the response time and types of persons requesting information. It is suggested that finding a greater number of variables in the future will only allow the evaluation of productivity, efficiency, quality, and impact of the Drug Information Service.

The pharmacovigilance program has led to the identification of ADRs, and subsequently their notification to the National Center for Pharmacovigilance and doing so according to the norms of Mexican Pharmaceutical Policy for Drug Safety. Because the suspected cases of ADR can be classified according to the Granada Consensus as drug-related problems of type 5 or 6 , we identified a need and made corresponding pharmaceutical interventions.

The pharmacotherapy follow-up program has allowed us to detect different drug-related problems and develop pharmaceutical interventions for patients at the late stages of illness, in addition to achieving active participation by the pharmacist involved in the multidisciplinary health team's decision making process. In the future we will provide satisfaction grade data from the medical group relating to the pharmaceutical interventions that were made. 


\section{CONCLUSIONS}

The systems and programs developed by the Comprehensive Center of Pharmaceutical Services at the Palia Institute have imported information related to drug use, opportunities available for the pharmacist who is proclaimed as an integral part of a multidisciplinary health team, and the resolution of drug-related problems in Mexico. We expect that the Integral Center of Pharmaceutical Services will be a model for other health institutions serving the cause of patient health care.

\section{ACKNOWLEDGMENTS}

We acknowledge Professional Editors \& Writers for their proofreading services.

\section{CONFLICT OF INTEREST}

None declared.

\section{References}

1. El papel del Farmacéutico en el Sistema de Atención de Salud. Tokyo: OMS; 1993.

2. Rivera S, Lopez Orozco M. Design, implementation and assessment of a health education service on the correct use of drugs in a pediatric Mexican hospital. Pharmacy Practice. 2006; 4(1): 9-12.

3. Gutiérrez-Godinez J, Torres-Jácome J, Herrera EV, Albarado A, Ponce D, López-López JG. Seguimiento farmacoterapéutico de antiparasitarios para pacientes pediátricos de Santa Maria Acuexcomac-México. Seguimiento Farmacoterapéutico 2005; 3(3): 150-153.

4. D’Alessio R, Busto U, Girón N. Guía para el Desarrollo de Servicios Farmacéuticos Hospitalarios. Información de Medicamentos. Serie Medicamentos Esenciales y Tecnología OPS/OMS, No. 5.4. October 1997

5. Rodríguez de Bittner M, Girón Aguilar N. Guía para el Desarrollo de Servicios Farmacéuticos Hospitalarios. Atención farmacéutica al paciente ambulatorio. Serie Medicamentos Esenciales y Tecnología OPS/OMS, No. 5.5. October 1997

6. Machuca M, Fernández-Llimós F, Faus MJ. Método Dáder: Guía de Seguimiento Farmacoterapéutico. Granada: Universidad de Granada; 1999.

7. NORMA Oficial Mexicana NOM-220-2004, Instalación y operación de la farmacovigilancia. Diario Oficial de la Federación. 15 November 2004

8. Ley General de Salud de los Estados Unidos Mexicanos. Editorial Sista. México, March 2005

9. Comité de consenso. Segundo Consenso de Granada Sobre Problemas Relacionados con los Medicamentos. Ars Pharm 2002;43(3-4):175-184. 